\title{
Indonesian Foreign School Teachers' Perception And Capability To Undertake Classroom Action Research: Basis For Capability Building Program
}

\author{
Petrus Pati \\ The Indonesian School of Davao-Philippines Principal
}

\begin{abstract}
This academic study which is taken from March to October 2012 is anchored on the Theory of Planned Behavior (TPB) which states that teachers' capability to undertake classroom instruction is affected by their perception on classroom action research itself. It is conducted among 94 teachers in five different Indonesian Foreign Schools which are the Indonesian School of Davao, Philippines; the Indonesian School of Wasenar, Netherlands; the Indonesian School of Yangon, Myanmar; the Indonesian School of Cairo, Egypt; and the Indonesian School of Moscow, Russia, in order to know the relationship between their perception and capability to undertake classroom action research.

The findings of this study show that there is a significant relationship between teachers ' perception and capability to undertake classroom action research. Furthermore, their perception influences their capability to undertake classroom action research. About $7.45 \%$ of their perception affects their capability and about $92.55 \%$ of the other factors influenced the capability is not covered in this study.

Based on the findings, the capability building program is proposed in order to enhance teachers' perception and capability to undertake classroom action research. This program focuses on teachers' training and improving budget allocation for classroom action research.
\end{abstract}

Key Words: Research perception, research capability, capability building program

\section{Introduction}

Over the years, research has become a prevailing phenomenon of our civilization. Scholars, and graduate students in the academic discipline and professions are engaged in research. Research is conducted in various settings: classrooms, laboratories, barangays and even in foreign cultures. It is undertaken for the purpose of explaining and predicting phenomena. In the case of educational research, it has greatly influenced or affected teaching and learning and the operation of the school system (Zulueta \& Perez, 2010).

Although research identifies a plethora of evidence-based instructional practices, classroom teachers find research difficult to access and often have little relevance to classroom instruction. Therefore, teachers often do not use research-based instruction within their classrooms (Greenwood \& Abbot, 2001).

Of the 1,461,124 public school teachers in Indonesia, only few undertook classroom action research to increase their professional rank. Specifically, out of that number only 334,159 or $22.87 \%$ obtained level IV A, 2,338 or $0.16 \%$ gained level IV B, 88 or $0.006 \%$ achieved level IV C, 15 or $0.001 \%$ got level IV D and no teachers in level IV E. This data proved that only $2.50 \%$ of out of 1.461 .124 of Indonesian public school teachers or only few of Indonesian public school teachers undertook classroom action research. The reason why only few teachers doing classroom action research is that not all Indonesian public teachers came from the bachelor background, especially in elementary and junior high school teachers but some of them just only have teaching educational background certificate which gained three years after having the junior high-school diplomas. These teachers did not have capability in doing classroom action research (Kunandar 2008).

Bernardo (2003), in his study on the typology of higher education institutions (HEIs) in the Philippines, stated that only 15 out of 223 HEIs in the sample met the requirements for the graduate capable HEIs category, and only two HEIs met the criteria for doctoral/research university categories. This shows that majority of the HEIs are teaching institutions. It means only few teachers undertook research.

Since 2010, the researcher who is the principal of the Indonesian School of Davao, Philippines had allocated Rp.2.500.000,00 (roughly equivalent to Php 12,500.00) to support teachers to undertake classroom action research but not one from among the 13 Indonesian School of Davao, Philippines Teachers took it, and until 2012 no one of the teachers has done classroom action research yet. This is the urgency that the researcher wanted to unravel the teachers' inner drives and capability in conducting action research. The researcher is aware that several critical issues divide teachers from doing classroom action research making it difficult for the school to respond. The researcher believed that this research will help the Indonesian foreign schools in designing programs that could address the low turnout of research. 


\section{Previous Work}

The following are the related previous work that would supplement this study with required review of the established concepts, academic papers, and studies concerning the general elements of this research. However, this previous work is directed and structured towards providing depth and substantial understanding about the perception and capability of teachers in conducting classroom action research.

\section{Teachers' Perception on Action Research}

Apruebo (2005) defined perception as the process of organizing awareness and interpreting sensory input in order to give meaningful experience. Therefore teachers' perception refers to the insights teachers regarding classroom action research (such as their perception on time, subject taught, cost, and other supports from the administrators) where classroom action research is a systematic approach to investigation that enables people to find affective solutions to problems they confront in their everyday lives. It is particularly useful as an approach to problems of practice; that is, problematic situations in which the investigator is concerned with more than simply understanding the phenomenon in order to direct it to some desired end and it is typically described as a cyclical process in which investigator proceed through multiple cycles of problem identification, data collection, analysis of data to a fuller understanding of the problem at hand, and eventually, to testing of interventions which are in turn subjected to the same process of data collection, reflection, etc. until an adequate solution to the problem at hand is achieved. All of this process in doing classroom action research depends on how teachers perceived the classroom action research itself, and time is the main factor in their perception towards research.

Eggen and Kauchak (2001) gave cognitive dimension of perception. They see perception as the process by which people attach meaning to experiences. They explained that after people attend to certain stimuli in their sensory memories, processing continues with perception. Perception is critical because it influences the information that enters working memory. Background knowledge in the form of schemes affects perception and subsequent learning. Research findings have corroborated this claim that background knowledge resulting from experience strongly influence perception.

Budi Prasetyo A.P (2010) stated that teachers' perception on action research is the process by which teachers perceived classroom action research as the instructional improvement. He found out that there are some factors that affected teachers' perception on classroom action research such as knowledge, classroom action research training, school culture, leadership styles, and teachers' motivation to improve their instructional in the classroom. These factors significantly affect their perception in doing classroom action research.

On the other hand, a common response from teachers when it is suggested they engage in research in their classrooms is often some combination of surprise, disbelief, and wariness. Their responses are linked to images of research involving highly technical routines of investigation engaging sophisticated research instruments and complex statistical analysis. The teachers cannot imagine that they would have the time or the inclination to engage in such activity, or that it would serve any useful purpose. The teachers' perception in doing classroom action research in terms of image affects significantly their capability to do action research (Stringer, 2004).

The teachers' ability to seek out, critically evaluate and integrate appropriate evidence from research and innovation is recognized as an important aspect of effective development in professional practice. It is central to the ability to cope with the rapidly expanding knowledge base and the increasing pace of change characteristic of an information society. Its importance in critical reflection and decision-making, and engagement in creating and effecting change, is recognized in evidence-based practice initiatives. In education, the concept of research-based teaching as part of reflective practice has been influential for many years. Teachers who are more reflective usually have higher perception on classroom action research since they wanted to improve their instructional. Stenhouse's reflections on research-based teaching presented the case not only for the teacher as action researcher but the teacher-researcher who tests out the application of other people's research findings in their own classroom (Ruddock and Hopkins, 1985). He found out that these teachers have good perception in doing classroom action research since they have intrinsic motivation to do action research.

Little and King (2007) maintained that perception on research as well as classroom action research from teachers is important since the main function of research is to improve research procedures through the refinement and extension of knowledge. The refinement of existing knowledge or the acquisition of new knowledge is essentially an intermediate step toward the improvement of the social studies. They found out that teachers' perception in doing classroom action research depends on their image on classroom action research.

However, Williams and Coles (2003) contend that evidence suggested that teachers felt reasonably confident about seeking general information, though their confidence was likely to be restricted to their knowledge of the relatively narrow range of sources they use more frequently. They tended to see the process of 
seeking and evaluating research information as more of a challenge, and confidence levels were lower in the primary and nursery sectors than in the secondary sector. Although they expressed some uncertainty about search strategies, teachers generally felt least confident in the area of evaluating and using (organizing, synthesizing, communicating) research outputs and, indeed, information generally. Many of the judgments that they made appeared to be less concerned with quality in terms of validity and reliability of evidence and more concerned with whether the research addressed classroom reality.

Furthermore, the above authors averred that teachers tended to give greater weighting to factors such as applicability of the research topic and conclusions than to objectivity, lack of bias, appropriate methodology and the presence of sufficient evidence to support conclusions. It is also clear that there was a close relationship between confidence in information handling and attitudes towards research and previous involvement in research. This may be linked to a greater awareness of the research process which brings more confidence in making judgments about relevance and quality of information.

Oja and Pine (1989); Henson (1996); and Rust (2007) confirmed that several evidence suggest that teachers who have been involved in research may become more reflective, more critical and analytical in their teaching, and more open and committed to professional development.

Furthermore, this theory was supported by Budi Prasetyo A.P (2010), stating that classroom action research often comes from teachers' reflection of their practices. They often reflect on their teaching which can help students more competent as well as good behaves. The reflective teachers never felt satisfaction on their teaching when they found any problems in their classroom.

On the other hand, Kunandar (2008) stated that teachers' perception on classroom action research is influenced by time, cost, image, technically, and effort.

Time. Kunandar (2008) stated that some teachers argued that doing classroom action research needs a lot of time. It is difficult for them to undertake classroom action research while teaching since they have teaching loads. Therefore, classroom action research could be done only if teachers are deloaded of their subject loads and are not involved in school activities. On the other hand, some teachers argued that doing classroom action research can be carried out without using a lot of time as long as it is planned well. This view is supported in the exploratory research conducted by Sharobeam and Howard (2002) among 127 undergraduate institutions in the United States of America. They had categorized two top factors hindering the teachers to undertake classroom research. First is the time, they admitted that they do not have the luxury of time. Second is the teaching load, which seems to be another way of saying that they are preoccupied and have no time in engaging into research.

Clemena Rose Marie Salazar, and Sherlyne A. Almonte-Acosta (2012) stated that the factors necessary to improve research productivity include: time, strong belief in research endeavor, faculty involvement, positive group climate, working conditions, and organizational communication, decentralized research policy, research funding, and clear institutional policy for research benefits and incentives. Therefore, developing a research culture should take into account the dynamics of the interaction of the trifocal function of HEIs, the teachers' mind, and the body of institutional policy. Many of the respondents consider teaching as their main task whereas research is only an add-on activity. Teaching occupies most of their time in their respective colleges or universities; consequently, there is not enough time to conduct the research. Time is therefore considered as a factor that affects research activity since time that is supposedly spent for research is allotted instead to teaching preparation and development of teaching materials.

In a qualitative study, Blasé (1986) examined teachers' perceptions of workplace stress. Ten major categories of perceived sources of significant stress were identified. The dominant category was organizational stressors (e.g., lack of time, lack of sources, excessive paper work, roles over load, etc) with time appearing as a factor in several of the other stressor categories as well as. He emphasized the importance that time plays in all aspects of teachers stress. Teachers' stress in terms of time influenced them to do action research.

Maja Miskovic, Efrat Sara Efron, and Ruth Ravid (2012) in their study on "Action Research in Action: From University to School Classrooms," stated that the commitment of teachers to engage in practitioner research is not without problems. Critics for example question the validity of practitioner inquiry and feel that teachers lack sufficient research skills and do not trust their ability to collect and interpret data. In addition, we need to investigate what are the conditions that facilitate or obstruct the disposition and ability of educators to research their own practice and how to reduce the inherent tensions between teaching and researching. Some teachers, especially beginner teachers, find themselves overwhelmed by the demands of their work and feel that they do not have time to be involved with an inquiry that seems to be an additional, unnecessary activity. They may also not feel comfortable in looking critically at the educational conditions of the school or challenging established assumptions. They stated that the main barrier to conducting teacher research is lack of time with mean of 3.43 on a 4-point scale.

In an observation done by Meiland and Rosenthal (1995) and Winkler (1996), teachers have to contend with competing demands between teaching and research. Thus, teachers are placed between two big stone. 
Conversely, teachers argued that higher teaching load aside from the student-teacher ratio minimize their research productivity and other scholarly activities.

Similarly, Meyer (1998) in his research among the predominantly undergraduate institutions in the United States of America had concluded that time is the most limiting factor in conducting research since more time is devoted to teaching. Teachers devote more time teaching at the same time balancing with research activities and community service. As a result, most teachers decide to conduct their summer class recess and holidays.

Cost. Doing research needs a lot of money for the teachers to engage in classroom action research. Teachers argued that the impact of doing classroom action research is financially draining. Additionally, their income in their professional rank couldn't overcome the cost in doing classroom action research (Kunandar, 2008). Not only Kunandar (2008) stated that cost influenced teachers' perception in doing classroom action research but also Clemena Rose Marie Salazar and Sherlyne A.Almonte-Acosta (2012) stated that one of the factors necessary for improving research productivity is research funding and incentives.

Image. For the teachers who had gotten the increase of their professional rank argued that the income that they got after the increase of their salary is not the main reason not to explore action research but the pride as a professional teacher. For them, the challenge of doing classroom action research is the main factor (Kunandar, 2008). Little and King (2007) reported that after the completed on line course in action research, the respondents stated that the process of that course was very important to their teaching within the classroom. And all of the respondents reported that they learned about their own students' learning. In addition, $78 \%$ of the respondents reported that they strongly believed that they were learning to be more effective teachers.

Technicality. Not all Indonesian public teachers came from the bachelor background, but some of them just only have teaching educational background certificate which gained three years after having the junior highschool diplomas. These teachers did not have capability in doing classroom action research. On the other hand, teachers who graduated from bachelor background are able to do classroom action research since the requirement of the universities (Kunandar, 2008). This observation was supported by Bragida (1997) and Antonio (1997) cited by Chagas (2005) who stressed that training in research is of importance as one of the means in attaining quality and excellent teachers. This means that development programs and activities in research, scholarship, and faculty and staff development are needed to motivate the teacher to engage in research.

Effort. In the training of doing classroom action research, the teachers complained that it was stressful for them to find out the classroom problems that can be used as their classroom action research topic. Therefore, some of them argued that doing classroom action research is effortless. But for the teachers who had been experienced in doing classroom action research argued that it is easy to find out the classroom problems and finding out line steps (Kunandar, 2008). Furthermore, Clemena Rose Marie Salazar and Sherlyne A. Almonte-Acosta (2012) stated that since many faculty members are focused on teaching and consider themselves as teaching faculty, there must be strategies to address their belief in the research endeavor. Motivational factors and situational contingencies must be considered to change the belief of the faculty members towards research.

Furthermore, Blasé (1986) stated that there is some degree of strain (the result of stress) in all occupational settings, and the level of stressors among teachers is not a new concern. Workload, class size, students behavior problems, inadequate administration support, lack of professional training, lack of resources, teaching outside the area of specialization, time pressures, and classroom action research have all been noted as issues of concern for teachers. The stress influenced teachers' perception in doing classroom action research.

According to Catane (2002) teachers' aptitude and enthusiasm are of importance in undergoing research. He said:

"Research requires special skills on the part of the researcher. These skills can be taught and learned provided one has the aptitude and interest. Without proper aptitude and interest, research would not be a significant endeavor to the researcher." This goes to show that conducting research is a result of teachers' effort and commitment. It goes further without saying that the teachers are the vital element in doing research.

Age. According to Kooij, Jansen, de Lange, and Dikkers (n.d), literature reviews indicate that most age-related factors can have a negative impact on the work motivation of older workers. However, this view was contradicted by previous study conducted by Paynter (2004) and Rhodes (1983) who found a positive relation between age and work motivation. In this study, the researcher wanted to find out whether age influences the motivation of teachers in the conduct of action research. According to Maksum, Etty Andriani, Eka Kusmayadi and Tuti Sri Sundari (2010) the age of 25-56 is the age of productive age, where in this age the capability to produce something is in the top of the age.

In a study conducted by Lindner (1998) regarding the motivating factors that affect the conduct of research among the employees of Ohio State University Research and Extension Center, he found 10 motivating reasons in the conduct of research. These were (a) interesting work, (b) good wages, (c) full appreciation of work done, 
(d) job security, (e) good working conditions, (f) promotions and growth in the organization, (g) feeling of being in on things, (h) personal loyalty to employees, (i) tactful discipline, and (j) sympathetic help with personal problems.

Furthermore, in a study piloted by Kovach (1987) among industrial employees yielded the following ranked order of motivational factors: (a) interesting work, (b) full appreciation of work done, and (c) feeling of being in on things. Another study of employees, conducted by Harpaz (1990), generated the following ranked order of motivational factors: (a) interesting work, (b) good wages, and (c) job security.

In the above studies, it is interesting to note that pay (the money involved in the conduct of research) was not ranked as one of the most important motivational factor as one might thought but the kind of job the employees are into. The discrepancies in these research findings support the idea that what motivates employees differs given the context in which the employee works - teaching, field, etc. What is clear, however, is that employees rank interesting work as the most important motivational factor.

\section{Teachers' Capability to do Action Research}

Action research is a systematic approach to investigation that enables people to find effective solutions to problems they confront in their everyday lives. It is particularly useful as an approach to problems of practice; that is problematic situations in which the investigator is concerned with more than simply understanding the phenomenon in order to direct it to some desired end. As such, action research is typically described as a cyclical process in which investigator proceed through multiple cycles of problem identification, data collection, analysis of data to a fuller understanding of the problem at hand, and eventually, to testing of interventions which are in turn subjected to the same process of data collection, reflection, etc. until an adequate solution to the problem at hand is achieved. This process needs certain knowledge and skills. The knowledge can be included in the teachers' educational background and, research training seminar, and having an experience in doing classroom action research (Kemmis and McTaggart, 2000). Therefore teachers' capability to undertake classroom action research depends on their knowledge, skills and their own motivation in doing classroom action research.

In the same vein, Sandra, Andriani, Antoro, Prayekti, and Warsito (2011) affirmed that action research on the teaching-learning process in classrooms-classroom action research (CAR) - is a similar systematic process aimed at gathering information on teaching and learning problems in the classroom and working toward their solution. CAR is on-going process of problem formulation, preparation of interventions, implementing interventions, observation and analysis of results, and reflection. Thus it often proceeds through several cycles before a satisfactory solution is found. Some teachers claimed that even they are bachelor degree but they still don't know how to undertake it since when they were in the university the topic of classroom action research is not an essential one.

In action research or classroom action research, the teacher becomes the primary researcher. As the researcher, the teacher has a vital role in developing, implementing, and analyzing problems experienced within the classroom. Through action research, the teacher is able to make effective decisions about what to teach and how to select the best content, methods, or strategies for their students. The respondents often argued that they don't have confidence in doing classroom action research because of lack of capabilities. (Little \& King 2007)

In Indonesia, DepEd Order No. 16 (2007) about academic and competency standard of teachers stated that all teachers are required to have an academic standard, pedagogy standard, social standard, and personal standard. One of pedagogy standards stated that all teachers are asked to have a reflective thinking in order to improve the quality of teaching and learning process. There are three kinds of reflective thinking, they are reflective thinking to the teaching and learning process that had been carried out, using the result of reflective thinking to improve the quality of teaching and learning process in the class, and undertaking classroom action research in order to improve the quality of teaching and learning process in the class. This is one of the way teachers are forced to undertake classroom action research, therefore school principal in his planning of school development should include teachers' capability development program in order to improve teachers' capacity to conduct action research (Kunandar, 2008)

This requirement has been implemented in 1995 because according to the Indonesian DepEd Order No. 025/O/1995 stated that every public teacher who has the level of IVA and wanted to increase the level of IVB, and from IVB to become IVC, and from IVC to become IVD, and from VID to become IVE (the highest level of public teacher) are asked to collect 12 units from Professional Development. Professional development is teachers' activities in order to implement the knowledge, science, and skills to improve the quality of teaching and learning process in the class and to improve the quality of teachers' profession. There are different kinds of professional developments they are undertaking class room action research, presenting working paper in a seminar, books and modules writing, publishing the result of research in a journal, and invention applied 
technology and etc. Even though this requirement has been implemented for a long time but only $2.50 \%$ of the Indonesian Public Teachers undertook classroom action research. The rest of them could not undertake classroom action research because they did not have capability to undertake it. (Kunandar, 2008)

Budi Prasetyo A.P (2010) stated that teachers' capability to undertake classroom action research is influenced by their educational background. Educational background which reflects their knowledge and skills in doing classroom action research affects the capability of the teachers' in doing classroom action research. He stated that teachers' educational background influenced significantly the capability to undertake classroom action research especially in Central Java, Indonesia.

Moreover, Supraptono Eko (2012) stated that teachers' performance in doing classroom action research in Semarang, Central Java, Indonesia is still lower. He found out that there are many variables influenced teacher's capability in doing classroom action research. He found out that teachers' performance in doing classroom action research was affected by teachers' motivation in doing classroom action research, teachers' competency, and school culture, leadership style, and teachers' training. He stated that from 236 teachers who had been his respondents, the results shown that teachers' performance in doing classroom action research significantly was influenced by teachers' motivation in doing classroom action research, teachers' competency, and school organization' culture. Teachers' competency, motivation, and school organization culture influenced significantly their capability to undertake classroom action research. Teachers' training also significantly influenced the capability of teachers in doing classroom action research.

Kunandar (2008) found out that the capability of teachers to undertake classroom action research depends on the teachers' knowledge and skills.

Knowledge. Teachers who had an experience in doing classroom action research usually know how to undertake it. They can differentiate the difference parts of research. But teachers who are fresh graduate from universities and who didn't have an experience in doing classroom action research found it was difficult to undertake it (Kunandar, 2008). Clemena Rose Marie Salazar and Sherlyne A.Almonte-Acosta (2012) also stated that there are 3 domains in research culture, one of the domain 2 which is the individual attitudes and output refers to the knowledge, skills, that the faculty members possess relative to the conduct of the research. This also includes their readiness, capacity and experience as regards research. Their output in domain 2 on the other hand, is based on their knowledge about producing research.

Furthermore, Cuizon and Cayogyog (2011) stated that knowledge and skills refers to one's capability. It proved one's ability in doing research.

Skills. After training teachers in doing classroom action research, it found that the participants gained 85 percent of the skills needed to undertake classroom action research. It proved that doing classroom action research needs certain skills not only find out the classroom problems and the steps in doing it but also the computation and how to write classroom action research report (Kunandar, 2008).

Maja Miskovic, Efrat Sara Efron, and Ruth Ravid (2012) in their study on "Action Research in Action: From University to School Classroom," stated that the teachers felt between somewhat competent and competent on all the research competencies and skills. The teachers felt most competent in identifying and posing research questions. These skills included the ability to review and synthesize existing literature on a topic interest, analyze and interpret data they collected, and report on their study. Teachers were somewhat less sure about their ability to plan research studies and design appropriate data collection tools with mean of 2.70 at a 4-point scale.

Furthermore, Cuizon and Cayogyog (2011), mentioned that the knowledge and skills of someone to do research refers to the ability of that person to do research.

Reason. Teachers need help. They want help, too. But they need and want the right kind of help. There are many way in helping teachers (DiGuilio, 2000). Continuous professional development, giving incentive, and motivating teachers to undertake classroom action research are the examples of helping teachers. Clemena Rose Marie Slazar and Sherlyne A.Almonte-Acosta (2012) also stated that many of the faculty members are not doing research due to a lack of confidence in their research capabilities.

Furthermore, teachers should have motivation in doing research. Therefore, the school principal factor played an important role in improving the performance of the school. The school principal should motivate the teachers so the teachers are motivated and challenged in doing research (Aritonang, 2007).

Additionally, Cuizon and Cayogyog (2011) found out that even the respondents are highly aware that research works are responsibilities that are worth indulging. The respondents also convinced of the usefulness and value of doing research, but on the other hand, the research works are demanding, expensive, time consuming and 
they entail a lot of complexities. These are the reasons why teachers are not engaging themselves in doing research.

\section{Relationship between Teachers' Perception and Capability to Do Action Research}

In a research conducted by Williams and Coles (2003) showed that attitudes of teachers towards research tended to vary significantly in relation to research experience, subjects taught, and age. Results of their research revealed that teachers currently taking part in research-based study tended to be more positive about research. Those who had undertaken action research at sometimes also tended to be more positive. Moreover, attitudes towards research also varied in relation to specific subjects taught. Those teaching Math tended to be more negative about research than the sample as a whole. Data also tended to suggest that teachers of social and environmental subjects may also be less positive about research. Attitudes amongst those who taught communications related subjects (excluding languages), sciences and ICT/technical subjects reflected the general patterns across the sample as a whole. Numbers teaching other subjects including languages and business and management subjects were too low to allow any meaningful statistical assessment of subject related trends in attitudes towards research although overall those teaching science and technology were less positive about research compared to those in arts and humanities or other subjects. Furthermore, attitude also varied significantly with age. Teachers in the age band of 20-30 tended to be more positive about research. However, length of time in teaching did not prove significant. The gender of the respondent was significant, with women being more likely to be positive about research than men. While the numbers involved precluded meaningful measure of significance, figures suggest strong trends in attitudes according to the position held in school.

Kunandar, 2008) found out that the relationship between teachers' perception and capability to undertake classroom action research has 0.50 correlation. This means that as the perception of the teachers to undertake classroom action research increases, the capability to undertake it also increases.

Budi Prasetyo A.P (2010) found out that only 36.6\% primary school teachers (total 187) had good educational background, $39.6 \%$ teachers experienced a strong conducive school culture, $34 \%$ show strong positive perception and attitude (41.2\%), and $41.7 \%$ teachers showed their strong meta cognitive awareness. The findings also showed that teachers' educational background, school culture, perception, attitude, intrinsic motivation and meta cognitive awareness all together had significantly an impact on the implementation of classroom action research ( $\mathrm{F} 4.389, \mathrm{p}$ 0.000) Simultaneous contribution of those variables toward classroom action research was $12.8 \%\left(\mathrm{R}^{2} 0.128\right)$. Teachers' educational background and perception significantly influenced the capability to undertake classroom action research.

Moreover, Supraptono Eko (2012) stated that teachers' capability to undertake classroom action research was influenced significantly by teachers' perception in doing classroom action research and competency. Teachers' training also significantly influenced the capability of teachers in doing classroom action research.

Maja Miskovic, Efrat Sara Efron, and Ruth Ravid (2012) in their study on "Action Research in Action: From University to School Classroom," stated that the teachers' perception in doing classroom action research significantly influenced their capability to undertake classroom action research.

Clemena Rose Marie Salazar and Sherlyne A.Almonte-Acosta (2012) also stated that many of the faculty members are not doing research due to a lack of confidence in their research capabilities. This is due to their perception in doing research and support from the administration department. Teachers' perception significantly influenced their capability to undertake research.

Sandra, Andriani, Antoro, Prayekti, and Warsito (2011) revealed that teachers' perception affected significantly their capability to undertake classroom action research. There is about $12.75 \%$ of the teachers' perception influenced their capability to undertake classroom action research

Little and King (2007), stated that the teachers' perception significantly influenced their capability to undertake classroom action research. They found out that teachers' perception had significantly an impact on their capability to undertake classroom action research at (F 4.538, p 0.005).

The following literatures had helped the researcher gain insights regarding the variables of this research. The literatures explained the time, cost, image, technically, and effort as part of the teachers' perception. On the other hand, the literatures also elaborated the possible factors that affect teachers' capability such as knowledge, 
skills, and reason. Furthermore, the readings tackled other factors such as educational background, length of service, and the age.

\section{Capability Building Program}

One of the ways that the role of teachers has the potential to change is the expectation or the desire for teachers to become researchers. Stenhouse persuasively argued that, "it is not enough that teachers' work should be studied: they need to study it themselves." (Stnehouse, 1975). Since then the "teachers as researcher" movement has gained widespread support from academic as well as teachers (Kemmis \& McTaggart, 1988). Therefore capability building program should be held to support the teachers.

On the other hand, Kunandar (2008) stated that from 1.461.124 of Indonesian public schoolteachers only a few or about $2.50 \%$ of them undertook classroom action research. This situation happened because the teachers were lack of capability to undertake classroom action research, therefore capability program is necessary to be held for the teachers.

Maja Miskovic, Efrat Sara Efron, and Ruth Ravid (2012) in their study on "Action Research in Action: From University to School Classroom," stated that the teachers would be more likely to conduct action research if they could get support from their administrators. They also agreed that the research curses and training that they got would help reflect on their practice and then undertook action research.

DiGuilio (2009) suggested that there are many ways in helping teachers who had interest and enthusiasm in doing research. These are the continuous professional development, giving incentive, and motivating teachers to undertake classroom action research are some of the examples of helping teachers.

Bragida (1997) and Antonio (1997) cited by Chagas (2005) who stressed that training in research is of importance as one of the means in attaining quality and excellent teachers. This means that development programs and activities in research, scholarship, and faculty and staff development are needed to motivate the teacher to engage in research. Teacher's development or professional development, in a broad sense, refers to the development of a person in his or her professional role. More specifically, "Teacher development is the professional growth a teacher achieves as a result of gaining increased experience and examining his or her teaching systematically". Professional development includes formal experiences (such as attending workshops and professional meetings, mentoring, etc) and informal experiences (such as reading professional publications, watching television documentaries related to an academic discipline, etc). (Glatthorn, 1995)

Clemena Rose Marie Salazar and Sherlyne A.Almonte-Acosta (2012) also stated since many of the faculty members are not doing research because they have a lack of confidence in their research capabilities, providing appropriate research training for the faculty members is absolutely necessary. The enhancement of research capacity among faculty members should be an essential part of the faculty development program. Appropriate policies are needed to reach out to the novice faculty in order for them to be involved in research. Mentoring is seen as essential for faculty involvement. The administration must provide opportunities for junior faculty members to work together with expert researchers.

Igwe (2005) stated that there is no doubt that no educational system can rise above the quality of its teachers. This means to achieve a functional educational system, the teachers must be able to respond the educational changes meant to achieve such objective. Fear of change is very fundamental to human nature. Consequently, in most cases, teachers have tendency to resist on old practices. To alley fear of teachers, their capability to near with the new challenges must be built for improved performance.

He stated that capability is "the ability to understand or do something" and building is "an increase in the amount of something over a period of time". Building the capability of teacher in educational process, therefore, is conscious attempt at upgrading, renovating, and acquiring skills, abilities, and strategies that must increase consistently over time and enable teachers react appropriately to academic dynamics including professional training, lesson delivery, effective use of instructional materials, teachers communication skills, provision of effective role model, effective discipline and students' control, and improved conditions of service.

Little and King (2007) reported that the pre-test of their respondent before taking the online module for professional development in action research scored $(\mathrm{M}=16.64, \mathrm{~s}=.953)$ and the post-test scored $(\mathrm{M}=17.27, \mathrm{~s}=$ .827). It is important to note that scores on pre-test surveys were already relatively high with the average scores being 17/18 correct. This may have been due to the fact that the respondents are all master's level students and have had prior experience through their coursework or previous professional development on action research. 
Despite the fact that the mean score was already high, the post-test surveys still indicated growth. This means that this professional development in action research increase the teachers' capability to undertake classroom action research.

\section{Objectives of the Study}

The objectives of this study were as follow:

1. To find out the demographic profile of the Indonesian Foreign Teachers in terms of their educational background, length of service, and age.

2. To find out the level of the Indonesian Foreign Teachers' perception in conducting action research in terms of time, cost, image, technicality, and effort.

3. To find out the level of the Indonesian Foreign Teachers' capability to undertake action research in terms of knowledge, skills, and reason.

4. To find out if there is a significant difference in the Indonesian Foreign Teachers' level of perception in conducting action research when grouped according to their profile.

5. To find out if there is a significant difference in the Indonesian Foreign Teachers' capability to undertake action research when grouped according to their profile

6. To find out if there is a significant relationship between the Indonesian Foreign Teachers' perception and capability to undertake action research.

7. To find out if the Indonesian Foreign Teachers' perception significantly influences their capability to undertake action research.

8. To find out what capability building program can be designed basis on the findings.

\section{Hypothesis}

This study tests the null hypothesis on $\alpha 0.05$ level of significance;

1. There is no significant difference in the level of teachers' perception in conducting classroom action research when grouped according to: educational background, length of service, and age.

2. There is no significant difference in the level of teachers' capability to undertake classroom action research when grouped according to: educational background, length of service, and age.

3. There is no significant relationship between teachers' level of perception and capability to undertake classroom action research.

4. The teachers' perception does not significantly influence their capability to undertake classroom action research.

\section{Scope and Limitation}

This study focused on teachers' perception and capability of teachers to undertake classroom action research in (Sekolah Indonesia Luar Negeri) Indonesian Foreign Schools. This research is confined to five (5) Indonesian Foreign Schools, namely: the Indonesian School of Davao in the Philippines, the Indonesian School of Wessenar in the Netherlands, the Indonesian School of Yangon in Myanmar, the Indonesian School of Cairo in Egypt, and the Indonesian School of Moscow in Russia. Moreover, this study does not include Indonesian diplomats and staffs who worked in the consulates and embassies.

This study used email as medium of communication; thus, only those respondents who were able to send back their questionnaires were considered. In this study, 94 respondents were obtained from among the five Indonesian Schools in different parts of the world.

The beginning of this study is from March 2012 up to October 2012.

\section{Definition of Terms}

The following important terms were defined conceptually and operationally to provide common understanding of the concepts being discussed.

Perception. Conceptually, Apruebo (2005) defined this term as the process of organizing awareness and interpreting sensory input in order to give meaningful experience. Operationally, this term refers to the insights of Indonesian foreign school teachers in five different locations regarding classroom action research.

Capability. Conceptually, The New Lexicon Webster's Dictionary of English Language (2004) defines this term as the state of being capable to do something. Operationally, this term refers to the respondents' alacrity in doing action research categorized into knowledge, skills, and reason. 
Capability Building Program. Conceptually, The New Lexicon Webster's Dictionary of English Language (2004) defines this term as an approach to development that focused on understanding the obstacles that inhibit people, governments, international organizations and non-governmental organizations from realizing their development goals while enhancing the abilities that allow them to achieve measurable and sustainable results. Operationally, this term refers to the program that can increase the respondents' capability in doing classroom action research.

Teachers. Conceptually, this term refers to a person whose occupation is to instruct (Webster, 2002). Operationally, this term is used to refer to the respondents of this study. These teachers were employed in the Indonesian schools specifically in Indonesian School of Davao, Philippines, the Indonesian School of Wassenar in the Netherlands, the Indonesian School of Moscow in Russia, the Indonesian School of Yangon in Myanmar, and the Indonesian School of Cairo in Egypt.

Indonesian schools. Operationally, this term refers to the school outside of Indonesian territory. The existence of these schools is in accordance to Indonesian DepEd Order No. 191/81/01 and DFA No. 051/U/1981 series of 1981. At the moment, there are 14 Indonesian foreign schools.

\section{Research Local and Respondents}

\section{Methodology}

This study was conducted to the teachers of Indonesian Schools of Davao- Philippines, WasenarNetherlands, Moscow-Russia, Yangon-Myanmar, Cairo-Egypt. From the fourteen (14) Indonesian foreign schools identified, only five school principals confirmed their participation to this study. This study had total respondents of ninety-four (94) teachers with eighty-one (81) teachers coming from four Indonesia schools and thirteen (13) teachers from the Indonesian School of Davao. Administration and distribution of the research instruments were done by sending email to the school principals and asking them to forward the same via email to the researcher. But before the sending of the questionnaires, the researcher had a personal meeting with the four (4) Indonesian foreign school principals in Bali, Indonesia on May 2012. This process was done to ensure the willingness and commitment of each school to participate in this study.

Indonesian School of Davao-Philippines was established in 1980 in order to serve the diplomats' kids. Later on, this school is not only for the children of the diplomats but also Indonesian descendants who were born in Mindanao, Philippines. In the school year of 2011-2012, there were 104 students from elementary to high school with 13 teachers who served them. From these 13 teachers, only 9 teachers were Indonesians while others were Filipinos.

Indonesian School of Wassenar-Netherlands was established in 1965. It is also an embassy school that served the diplomats' children and other Indonesian families' children who worked or studied in the Netherlands. In school year 2011-2012, there were 50 students from elementary to high school. The school has 15 teachers.

Indonesian School of Moscow-Russia was established 1963. It is also an embassy school that served the diplomats' children. In school year 2011-2012, there were only 35 students with 9 teachers serving them.

Indonesian School of Yangon-Myanmar was established in 1966. It is an embassy school. But recently, it does not only cater to the diplomats' children but also to the local community. In school year 2011-2012, there were 426 students from kindergarten to high school with 41 teachers who served them. Among these teachers, only 7 are Indonesian and the rest are from other countries including the local teachers.

Indonesian School of Cairo-Egypt was established in 1956. It is an embassy school that served not only the children of diplomats but also Indonesian overseas workers. In the school year 2011-2012, there were 60 students from elementary to high school with 16 teachers serving them. (Indonesian School of Davao, Information System Management, 2012)

\section{Research Instruments}

This study utilized the descriptive-correlation method with universal sampling technique. This study used the researcher-made questionnaires following a five-point Likert scale. Additionally, the questionnaire employed the following measurements and equivalences: 5-Strongly Agree, 4-Agree, 3-Moderately Agree, 2Disagree and 1-Strongly Disagree. The instruments consist of three parts. Part I of the questionnaire drew out the demographics profile of the respondents while Part II obtained the perception and Part III obtained the readiness of the teachers in conducting action research. Specifically, the questionnaire on perception was subdivided into time, cost, image, technicality, and effort. Each category had five questions. On the other hand, the questionnaire on capability was also categorized into three; knowledge, skills, and reason. Similarly, each category had five questions. 
The said questionnaires were subjected to validation particularly in terms of measuring and ensuring the clarity of instruction, understandability of the words used and ideas presented, congruity to the theoretical and conceptual frameworks, adequacy of the measurement of the variables, coverage, independence and objectivity of items, and absence of double-barreled and double negative statements.

Quantitative method was used in this study. Mean was used to determine the level of perception and capability of the respondents in conducting action research. ANOVA was used to test the sifnificant difference between the level of teachers' perception and capability to undertake classroom action research when grouped according to their profile. Pearson-r was used to test the significant relationship of variables. And Linear Regression was used to test the significant relationship of two variables.

\section{Demographic Profile of the Respondents}

\section{Result And Discussion}

Presented in Table 2 is the demographic profile of the respondents. In terms of educational background, the data show that $70 \%$ of the respondents belong to bachelor degree holders. It is interpreted that the majority of the respondents lack the capability to undertake classroom action research since they never did research such a thesis. Data also show that about $3 \%$ of the respondents belong to under bachelor degree holders. It is also interpreted that they lack the capability to undertake classroom action research.

In terms of length of service, data show that $34 \%$ of the respondents have been teachers for 6 to 10 years. It is interpreted that they are new in serving their schools, therefore they seem to lack the capability to conduct classroom action research. The lowest length of service is $26-30$ years conspiring $4 \%$. It is interpreted that these respondents have experiences teaching there, but they are not too many.

In terms of age, $64 \%$ of the respondents who belong to the productive age which ranges from the age of 20-45. It is interpreted that these ages are productive to conduct classroom action research. Further, respondents who are in their late adulthood or $15 \%$ belong to 46 to 50 years old, while $20 \%$ are in the age of 51 years old.

Table 2

\section{Demographic Profile of the Respondents}

\begin{tabular}{|l|c|c|}
\hline \multicolumn{1}{|c|}{ Educational Background } & Frequency & Percentage (\%) \\
\hline Under Bachelor Degree (<S1) & 3 & 3 \\
\hline Bachelor Degree (S1) & 66 & 25 \\
\hline Masteral Degree (S2) & 23 & 26 \\
\hline Doctorate Degree (S3) & 2 & 34 \\
\hline Length of Service & 24 & 11 \\
\hline $1-5$ years & 32 & 10 \\
\hline $6-10$ years & 10 & 5 \\
\hline $11-15$ years & 9 & 4 \\
\hline $16-20$ years & 5 & 11 \\
\hline $21-25$ years & 4 & 3 \\
\hline $26-30$ years & 10 & 11 \\
\hline More than 31 years & & 23 \\
\hline Age & 3 & 14 \\
\hline $20-25$ years old & 10 & 14 \\
\hline $26-30$ years old & 22 & 15 \\
\hline $31-35$ years old & 13 & 20 \\
\hline $36-40$ years old & 13 & 14 \\
\hline $41-45$ years old & 19 & \\
\hline $46-50$ years old & & \\
\hline More than 51 years old & & \\
\hline
\end{tabular}

\section{Teachers' Perception in Doing Classroom Action Research}

Table 3 revealed the level of teachers' perception in conducting classroom action research in terms of time. The figures disclosed that the over-all mean of teachers' perception in conducting classroom action research in terms of time is 2.82 or moderate, indicating that the item is fairly evident in some occasions, meaning that doing classroom action research needs time. Doing classroom action research while teaching 
waste time has an average mean of 2.39 , this indicates that the item is seldom evident in few occasions, meaning that the most of respondents did not agree that doing classroom action research is a waste time but they agreed that they can undertake it while teaching. Specifically, classroom action research needs a lot of time got an average mean of 3.63 or high. This indicates that the item is relatively evident in many occasions, meaning that most of the respondents agreed that doing classroom action research needs a lot of time.

This result moderately confirms the findings of Cuizon and Cayogyog (2011) who found out that doing research is time consuming, Kunandar (2008) who found out that doing classroom action research entails a lot of time. Sharobeam and Howard (2002), Apruebo (2005), Blasé (1986), Clemena Rose Marie Salazar and Sherlyne A.Almonte-Acosta (2012), Maja Miscovic, Efrat Sara efron, and Ruth Ravid (2012), Meiland and Rosenthal (1995) and Wibkler (1996) also identified time as the leading factor hindering teachers to conduct action research, and Meyer (1998) who recognized time as the most limiting factor in research engagement.

Likewise, this result confirms the findings of Chagas (2005) who found that time is the reason why development of research culture among teachers is low. This is because teachers use most of their time in teaching, preparing of lessons, checking papers, recording and computing grades. He further stressed that if there is a little time left, it is used for personal needs. Thus, it takes commitment from the teachers to spare some of their time for research.

Table 3

Level of Teachers' Perception in Conducting Classroom Action Research in terms of Time

\begin{tabular}{|l|l|c|c|}
\hline No & \multicolumn{1}{|c|}{ Statement } & Average Mean & Descriptive Interpretation \\
\hline 1 & Classroom action research needs a lot of time. & 3.63 & High \\
\hline 2 & Classroom action research does not affect by workload. & 2.89 & Moderate \\
\hline 3 & Classroom action research requires less time. & 2.46 & Low \\
\hline 4 & $\begin{array}{l}\text { Conducting classroom action research while teaching means waste } \\
\text { time. }\end{array}$ & 2.39 & Low \\
\hline 5 & $\begin{array}{l}\text { Time is not an important element in doing classroom action } \\
\text { research. }\end{array}$ & 2.73 & Moderate \\
\hline & \multicolumn{1}{|c|}{ Total Mean } & 2.82 & Moderate \\
\hline
\end{tabular}

Shown in Table 4 is the level of teachers' perception in conducting classroom action research in terms of cost. The information exhibits that the overall average mean of teachers' perception in conducting classroom action research in terms of cost is 3.31 or moderate which indicates that the item is fairly evident in some occasions, meaning that doing classroom action research needs certain amount of money. In particular, classroom action research involves less budget obtained an average mean of 3.13 or moderate, indicating that the item is fairly evident in some occasions, meaning that doing classroom action research can be done at minimum expense. Finally, classroom action research can be done at minimum expense obtained an average mean of 3.50 or high, indicating that the item is relatively evident in many occasions which means that doing classroom action research can be done at minimum expense.

This result fairly contradicts with Kunandar (2008) and Clemena Rose Marie Salazar and Sherlyne A. Almonte Acosta (2012) who posited that doing research was costly and financially draining. More so, this finding in some way or another reinforces the study of Lindner (1998), Kovach (1987), and Harpaz (1990) who did not find the cost of research as justifying factor for teachers not to engage in research.

Additionally, this result does not favor the findings of Cuizon and Cayogyog (2011) who found out that doing research is expensive.

Table 4

Level of Teachers' Perception in Conducting Classroom Action Research in terms of Cost

\begin{tabular}{|l|l|c|c|}
\hline No & \multicolumn{1}{|c|}{ Statement } & $\begin{array}{c}\text { Average } \\
\text { Mean }\end{array}$ & Descriptive Interpretation \\
\hline 1 & Classroom action research can be done at minimum expense. & 3.50 & High \\
\hline 2 & Classroom action research is inexpensive. & 3.40 & Moderate \\
\hline 3 & Money is not an issue in conducting classroom action research. & 3.18 & Moderate \\
\hline 4 & Classroom action research is not an expensive pursuit. & 3.36 & Moderate \\
\hline 5 & Classroom action research involves fewer budgets. & 3.13 & Moderate \\
\hline & Total Mean & 3.31 & Moderate \\
\hline
\end{tabular}


Table 5 exposed the level of teachers' perception in conducting classroom action research in terms of image. The data revealed that the over-all mean of teachers' perception in conducting classroom action research in terms of image is 3.76 or high which indicates that the item is relatively evident in many occasions, meaning that most of them have a good image in doing classroom action research. Particularly, while classroom action research can be a source of money gained an average mean of 2.57 or moderate, indicates that the item is fairly evident in some occasions which means that they did not agree that doing classroom action research can give much money but they still agreed that doing classroom action research would give them money. Finally classroom action research builds trustworthiness and reliability secured an average mean of 4.09 or high. This indicates that the item is relatively evident in many occasions, meaning that the respondents agree that doing classroom action research builds trustworthiness or reliability. This is in consonance with the findings of Stringer (2004) who says that a common response from teachers when it is suggested they engage in research in their classrooms is often some combination of surprise, disbelief, and wariness. Their responses are linked to images of research involving highly technical routines of investigation engaging sophisticated research instruments and complex statistical analysis. This is also in consonance with the findings of William and Coles (2003), Kunandar(2008), Little and King (2007), Srtinger (2004), Oja and Pine (1989), Henson (1996), Rust (2007) and Clemena Rose Marie Salazar and Sherlyne A Almonte Acosta (2012) who say that teachers who has involved in doing classroom action research, and attending in research training usually have good image in doing classroom action research.

Table 5

Level of Teachers' Perception in Conducting Classroom Action Research in terms of Image

\begin{tabular}{|l|l|c|c|}
\hline No & \multicolumn{1}{|c|}{ Statement } & $\begin{array}{c}\text { Average } \\
\text { Mean }\end{array}$ & Descriptive Interpretation \\
\hline 1 & Classroom action research boasts credibility. & 4.01 & High \\
\hline 2 & Classroom action research builds trustworthiness or reliability & 4.09 & High \\
\hline 3 & Classroom action research increases professional rank. & 3.87 & High \\
\hline 4 & Classroom action research can give much money. & 2.57 & Moderate \\
\hline 5 & Classroom action research improves image. & 4.24 & High \\
\hline & Total Mean & 3.76 & High \\
\hline
\end{tabular}

Shown in Table 6 is the level of teachers' perception in conducting classroom action research in terms of technicality. It is revealed in the data that the over-all mean of teachers' perception in conducting classroom action research in terms of technicality is 3.17 or moderate, indicating that the items is fairly evident in some occasions, which means that they do not have high technicality in doing classroom action research therefore they still need to be guided in some parts of the research technicality. In particularly, classroom action research is difficult to do obtained an average mean of 2.91 or moderate, indicating that the item is fairly evident in some occasions, meaning that the respondents in the middle of agreement that doing classroom action research is difficult to do. The highest level of average mean is guide is needed in doing classroom action research obtained an average mean of 3.41 or moderate. This indicates that the item is fairly evident in some occasions, meaning that the respondents agreed that they still need to be guided in doing classroom action research.

This is in consonance with Chagas (2005) in his study pointed out that technicality and training among teachers is moderately extensive. He found out that if schools positively respond to invitations for research training outside the school, only few selected teachers were sent due to limited funds. Unfortunately, these teachers who sent out seldom conduct an echo seminar to their colleague. Thus, knowledge on research was not extensively share among peers. It is also in consonance with Stringer (2004), Oja and Pine (1989), Henson (1996), Rust (2007), Sharobeam \& Howard (2002), Maja Miskovic, Efrat Sara Efron and Ruth Ravid (2012).

Table 6

Level of Teachers' Perception in Conducting Classroom Action Research in terms of Technicality

\begin{tabular}{|l|l|c|c|}
\hline No & \multicolumn{1}{|c|}{ Statement } & Average Mean & Descriptive Interpretation \\
\hline 1 & Classroom action research is easy to do. & 3.26 & Moderate \\
\hline 2 & Classroom action research is complex to do. & 3.23 & Moderate \\
\hline 3 & Classroom action research is difficult to do. & 2.91 & Moderate \\
\hline 4 & Finding a problem is easy in doing classroom action & 3.05 & Moderate \\
\hline
\end{tabular}




\begin{tabular}{|l|l|c|c|}
\hline & research. & & \\
\hline 5 & Guide is needed in doing classroom action research. & 3.41 & Moderate \\
\hline Total Mean & $\mathbf{3 . 1 7}$ & Moderate \\
\hline
\end{tabular}

Table 7 below show the level of the teachers' perception in doing classroom action research in terms of effort with the total average mean of 3.04 or moderate level. This indicates that the item is fairly evident in some occasions, meaning that the respondents are in the middle of agreement that doing classroom action research needs an effort. The lowest level of average mean of doing classroom action research in terms of effort is 2.55 or moderate level. This indicates that the item is fairly evident in some occasions meaning that the respondents are in the middle of agreement that doing classroom action research is effort. And the highest level of mean is 3.36 or moderate level. This indicates that the item is fairly evident in some occasions meaning that the respondents are in the middle of agreement that doing classroom action research is stressful. This is contradicted with the findings of Kunandar (2008), Clemena Rose Marie Salasar and Sherlyne A. Almonte Acosta (2012), Blasé (1986), and Catane (2002).

Table 7

Level of Teachers' Perception in Conducting Classroom Action Research in terms of Effort

\begin{tabular}{|l|l|c|c|}
\hline No & \multicolumn{1}{|c|}{ Statement } & $\begin{array}{c}\text { Average } \\
\text { Mean }\end{array}$ & $\begin{array}{c}\text { Descriptive } \\
\text { Interpretation }\end{array}$ \\
\hline 1 & Classroom action research is stressful. & 3.36 & Moderate \\
\hline 2 & $\begin{array}{l}\text { Classroom action research does not drain physical and mental } \\
\text { energy. }\end{array}$ & 3.24 & Moderate \\
\hline 3 & Classroom action research is easy to conduct. & 3.18 & Moderate \\
\hline 4 & Classroom action research is simple and undemanding. & 2.86 & Moderate \\
\hline 5 & Classroom action research is effortless. & 2.55 & Moderate \\
\hline & Total Mean & 3.04 & Moderate \\
\hline
\end{tabular}

Presented in Table 8 is overall the level of teachers' perception in conducting classroom action. The data reveal that the overall average mean of teachers' perception in conducting classroom is 3.22 or moderate, indicating that the items is fairly evident in some occasions, meaning that most of the respondents' perception in doing classroom action research is not good and not bad. Specifically, perception of image in conducting classroom action research has an average mean of 3.76 or high, indicating that the item is relatively evident in many occasions which means that their image in doing classroom action research is good, while cost perception obtained an average mean of 3.31 or moderate, indicating that the item is fairly evident in some occasions meaning that the respondents are in the middle of agreement that doing classroom action research needs certain amount of money, and technically perception obtained an average mean of 3.17 or moderate, indicating that the item is fairly evident in some occasions, meaning that the respondents do not have low technicality and neither have high technicality in doing classroom action research. Finally, perception of effort in conducting classroom action research acquired an average mean of 3.04 or moderate, indicating that the item is fairly evident in some occasions which means that the respondents' effort in doing classroom action research is not so high and not so low. Their effort in doing classroom action research is in the middle of effort. This moderate level of perception in doing classroom action research affects their capability to undertake classroom action research since according to Kunandar, 2008) who found out that the relationship between teachers' perception and capability to undertake classroom action research has 0.50 significant correlation.. This means that as the perception of the teachers to undertake classroom action research increases, the capability to undertake it also increases. But this is contradictive with Rudock and Hopkins (19985) who says that teachers with intrinsic motivation or reflective attitudes usually have good perception towards research.

Table 8

Overall Level of Teachers' Perception in Conducting Classroom Action Researches

\begin{tabular}{|l|c|c|}
\hline \multicolumn{1}{|c|}{ Indicators } & Mean & Description \\
\hline Time & 2.82 & Moderate \\
\hline Cost & 3.31 & Moderate \\
\hline Image & 3.76 & High \\
\hline Technicality & 3.17 & Moderate \\
\hline Effort & 3.04 & Moderate \\
\hline Over all & $\mathbf{3 . 2 2}$ & Moderate \\
\hline
\end{tabular}




\section{Teachers' Capability to Undertake Classroom Action Research}

Table 9 revealed the level of teachers' capacity to undertake classroom action research in terms of knowledge. It is revealed in the data that the over-all mean of teachers' capability in conducting classroom action research in terms of knowledge is 3.53 or high which indicates that the items is relatively evident in many occasions, meaning that most of them are capable to conduct classroom action research. The highest level is identifying whether the research is descriptive, experimental, correlation, or evaluative gained an average mean of 3.74 or high, indicating that the item is relatively evident in many occasions, meaning that the respondents are capable to identify whether the research is descriptive, experimental, correlation, or evaluative. The lowest level of teachers' capability is having an understanding what are MLS and APA formats obtained an average mean of 3.11 or moderate, indicating that the item is fairly evident in some occasions, meaning that most of them are not familiar with them. This is in consonance with the findings of Eggen and Kauchak (2001), Kemmis \& McTaggart (2000), Sandra, Andriani, Antoro, Prayekti and Warsito (2011), Little and King (2007), Kunandar 2008), Budi Prasetyo A.P (2010), and Supratono Eko (2012), who say that teachers' capability to undertake classroom action research depends on their knowledge which is reflected by their educational background, involving in research seminar, attending workshop on research, having an experience in doing classroom action research, and etc.

Table 9

Level of Teachers' Capability to Undertake Classroom Action Research in terms of Knowledge

\begin{tabular}{|l|l|c|c|}
\hline No & Statement & $\begin{array}{l}\text { Average } \\
\text { Mean }\end{array}$ & Descriptive Interpretation \\
\hline 1 & Can distinguish the different parts of research. & 3.55 & High \\
\hline 2 & Can understand the different types of research. & 3.62 & High \\
\hline 3 & Have ideas on how to start classroom action research. & 3.61 & High \\
\hline 4 & $\begin{array}{l}\text { Can identify whether the research is descriptive, experimental, } \\
\text { correlation, or evaluative. }\end{array}$ & 3.74 & High \\
\hline 5 & Understands what are MLS and APA formats. & 3.11 & Moderate \\
\hline & Total Mean & $\mathbf{3 . 5 3}$ & High \\
\hline
\end{tabular}

Presented in Table 10 is the level of teachers' capacity to undertake classroom action research in terms of skills. The data reveal that the overall average mean of teachers' capability to conduct classroom action research in terms of skills is 3.80 or high, indicating that the items is relatively evident in many occasions, meaning that they have skills in doing classroom action research. Moreover, ability to define words operationally has an average mean of 3.94 or high, indicates that the item is relatively evident in many occasions, meaning that the respondents are capable to define words operationally or they are able to conduct classroom action research. Specifically, formulating research problem has an average mean of 3.68 or high indicates that the item is relatively evident in many occasions meaning that the respondents are capable to conduct action research. This is in consonance with Kunandar (2008), who says that teachers who joined the research training gained the increasing of their skills towards research, and also Oja and Pine (1989), Henson (1996), Rust (2007), who says that teachers who have been involved in research become more skillful towards research. Furthermore it is also in consonance with Maja Miskovic, Efrat Sara Efron, and Ruth Ravid (2012) who say that teachers do not have sufficient research skills and do not trust their ability to collect and interpret data, and also Supratono Eko (2012) who says that teachers' research training influence significantly their skills in doing action research, and then Cuizon and Cayogyog (2011) who say that knowledge and skills affects the implementation of doing action research.

Table 10

Level of Teachers' Capability to Undertake Classroom Action Research in terms of Skills

\begin{tabular}{|l|l|c|c|}
\hline No & Statement & $\begin{array}{l}\text { Average } \\
\text { Mean }\end{array}$ & Descriptive Interpretation \\
\hline 1 & Can formulate a research problem. & 3.68 & High \\
\hline 2 & Can do simple statistical and inferential statistics. & 3.78 & High \\
\hline 3 & Can define words operationally. & 3.94 & High \\
\hline 4 & Can write unified, coherent, and emphatic sentences. & 3.77 & High \\
\hline 5 & Know how to take down notes and cite authors. & 3.79 & High \\
\hline & Total Mean & $\mathbf{3 . 8 0}$ & High \\
\hline
\end{tabular}


Presented in Table 11 is the level of teachers' capacity to undertake classroom action research in terms of reason. The data reveal that the overall average mean of teachers' capability to conduct classroom action research in terms of reason is 3.34 or moderate, indicating that the items is fairly evident in some occasions, meaning the respondents have reasons to do classroom action research. Specifically, motivating to do classroom action research because of their profession has an average mean of 4.12 or high. This indicates that the item is relatively evident in many occasions, meaning that the respondents agree that they do action research because of their professions. Finally, classroom action research is useless and giving no impact for them has an average mean of 2.42 or low, means that they didn't agree that doing classroom action research is useless and giving no impact for them, but they agreed that doing classroom action research is useful and give impact on them. This is in consonance with DiGuilo (2000) who says that with the continuous professional development, teachers will have their own reason to do action research. In their non-research; Clemena Rose Marie Salazar and Sherlyne A. Almonte-Acosta (2012) say that many of the faculty members are not doing research due to a lack of confidence in their research capabilities. Aritonang in his study (2007) says that teachers have low reason and suggested that the school principal has to motivate the teachers to do research.

Table 11

Level of Teachers' Capability to Undertake Classroom Action Research in terms of Reason

\begin{tabular}{|l|l|c|l|}
\hline No & \multicolumn{1}{|c|}{ Statement } & $\begin{array}{c}\text { Average } \\
\text { Mean }\end{array}$ & \multicolumn{1}{|l|}{ Descriptive Interpretation } \\
\hline 1 & Motivated to do classroom action research because I am a teacher. & 4.12 & High \\
\hline 2 & Inspired to make action research because of the incentives. & 2.96 & Moderate \\
\hline 3 & Encouraged to carry out action research because of the promotion. & 3.09 & Moderate \\
\hline 4 & Challenged to do action research for my professional growth. & 4.09 & High \\
\hline 5 & Classroom action research is useless and has no impact. & 2.42 & Low \\
\hline & Total Mean & $\mathbf{3 . 3 4}$ & Moderate \\
\hline
\end{tabular}

Presented in Table 12 is overall the level of teachers' capability to undertake classroom action. The data reveal that the overall average mean of teachers' capability to undertake classroom action research is 3.56 or high, indicating that the item is relatively evident in many occasions, which means that the respondents of this study are capable to undertake classroom action research. Specifically, having reason in doing classroom action research obtained an average mean of 3.34 or moderate, indicating that the item is fairly evident in some occasions, meaning that the respondents have reasons to conduct classroom action research. While having knowledge to conduct classroom action research obtained an overall average mean of 3.53 or high, indicating that the item is relatively evident in many occasions, meaning that the respondents have knowledge to conduct classroom action research. Finally having skills to conduct classroom action research gained an overall average mean of 3.80 or high, indicating that the item is relatively evident in many occasions, means that the respondents have skills to conduct classroom action research. This is in consonance with Budi Prasetyo A.P (2010) who says that teachers' capability to undertake classroom action research is influenced by their educational background. Educational background which reflects their knowledge and skills in doing classroom action research affects the capability of the teachers' in doing classroom action research. Moreover, this is also in consonant with Supraptono Eko (2012) who says that teachers' performance in doing classroom action research are influenced by teachers' motivation in doing classroom action research, teachers' competency, and school culture, leadership style, and teachers' training. He stated that teachers' competency, motivation, and school organization culture influenced significantly their capability to undertake classroom action research. Teachers' training also significantly influenced the capability of teachers in doing classroom action research.

This is also in consonant with Kunandar (2008) who says that the capability of teachers to undertake classroom action research depends on the teachers' knowledge and skills. Furthermore, this is in consonant with Cuizon and Cayogyog (2011) who say that knowledge and skills refers to one's capability. It proved one's ability in doing research. The findings also confirm the study of DiGuilo (2009) who says that teachers need help. They want help, too. But they need and want the right kind of help. There are many way in helping teachers. Continuous professional development, giving incentive, and motivating teachers to undertake classroom action research are the examples of helping teachers. 
Table 12

Overall Level of Teacher's Capability to Undertake Classroom Action Researches

\begin{tabular}{|c|c|c|}
\hline Indicators & Mean & Descriptive Rating \\
\hline Knowledge & 3.53 & High \\
\hline Reason & 3.34 & Moderate \\
\hline Skills & 3.80 & High \\
\hline Over-all & $\mathbf{3 . 5 6}$ & High \\
\hline
\end{tabular}

The Significance Difference of Teachers' Perception and Capability to Undertake Classroom Action Research when Grouped According to Their Profile

Table 13 presents the result of the analysis of variance of the teachers' level of perception in conducting classroom action research when grouped according to educational background. As shown, it has a pvalue of 0.081 which is greater than 0.05 degree of confidence. Hence, the hypothesis was accepted. This indicates that there is no significant difference in the teachers' level of perception in conducting classroom action research when grouped according to educational background. This implies that the educational background of teachers does not affect their perception in doing classroom action research. It contradicts the claim of Eggen and Kauchak (2001), in their study on cognitive dimensions of perception, which says that background knowledge in the form of schemes affects perception and subsequent learning. This also contradicted with Budi Prasetyo A.P (2010) who says there are some factors affected teachers' perception on classroom action research such as knowledge, classroom action research training, school culture, leadership styles, and teachers' motivation to improve their instruction in the classroom. These factors significantly affect their perception in doing classroom action research.

This also contradicted with Stringer (2004) who says that, a common response from teachers when it is suggested they engage in research in their classrooms is often some combination of surprise, disbelief, and wariness. Their responses are linked to images of research involving highly technical routines of investigation engaging sophisticated research instruments and complex statistical analysis.

But this is in consonance with Little \& King (2007) who says that teachers' perception in doing classroom action research depends on their image on classroom action research.

This is also in consonance with Oja and Pine (1989); Henson (1996); Keyes (2000) and Rust (2007) who confirmed that several evidence suggest that teachers who have been involved in research may become more reflective, more critical and analytical in their teaching, and more open and committed to professional development. Therefore, teachers' educational background does not affect their perception in doing classroom action research.

This is also in consonance with Kunandar (2008) who says that teachers' perception on classroom action research is influenced by time, cost, image, technically, and effort.

Table 13

Analysis of Variance of the Teachers' Level of Perception in Conducting Classroom Action Research when Grouped According to Educational Background

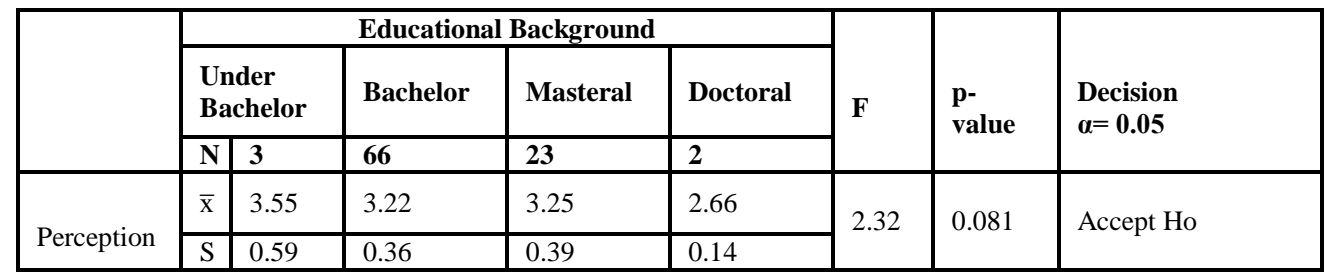

Shown in Table 14 is the result of the analysis of variance of the teachers' level of capability to undertake classroom action research when grouped according to educational background. As indicated, it has a p-value of 0.0348 which is greater than 0.05 degree of confidence. Thus, the hypothesis was accepted. This means that there is no significant difference in the teachers' level of capability in undertaking classroom action research when grouped according to educational background. This implies that the educational background of teachers does not affect their capability to conduct action research. This is contradicted with the findings of Supraptono Eko (2012) who says that from 236 teachers who had been his respondents in Semarang, Central Java, Indonesia the results shown that teachers' performance in doing classroom action research significantly was influenced by teachers' motivation in doing classroom action research, teachers' competency, and school organization' culture. Teachers' competency, motivation, and school organization culture influenced 
significantly their capability to undertake classroom action research. Teachers' training also significantly influenced the capability of teachers in doing classroom action research.

Table 14

Analysis of Variance of the Teachers' Level of Capability to Undertake Classroom Action Research when Grouped According to Educational Background

\begin{tabular}{|l|l|l|l|l|l|l|l|l|}
\hline & \multicolumn{5}{|c|}{ Educational Background } & \multirow{2}{*}{ F } & p-value & $\begin{array}{l}\text { Decision } \\
\mathbf{\alpha}=\mathbf{0 . 0 5}\end{array}$ \\
\cline { 2 - 6 } & $\begin{array}{l}\text { Under } \\
\text { Bachelor }\end{array}$ & Bachelor & Masteral & Doctoral & & \\
\cline { 2 - 6 } & $\mathbf{N}$ & $\mathbf{3}$ & $\mathbf{6 6}$ & $\mathbf{2 3}$ & $\mathbf{2}$ & & \\
\hline \multirow{2}{*}{ Capability } & $\overline{\mathrm{x}}$ & 3.53 & 3.54 & 3.54 & 4.27 & \multirow{2}{*}{1.11} & 0.348 & Accept Ho \\
\cline { 2 - 6 } & $\mathrm{S}$ & 1.24 & 0.54 & 0.52 & 0.00 & & \\
\hline
\end{tabular}

Table 15 reveals the result of the analysis of variance of the teachers' level of perception in conducting classroom action research when grouped according to length of service. As shown, it has a p-value of 0.548 . Such is greater than 0.05 degree of confidence. Therefore, the hypothesis was accepted. This means that there is no significant difference in the teachers' level of perception in conducting classroom action research when grouped according to length of service. This implies that the length of service of teachers does not affect their perception in doing classroom action research. It is in consonance with Eggen and Kauchak (2001), in their study on cognitive dimension of perception; say that background knowledge in the form of schemes affects perception and subsequent learning. Moreover it is also in consonance with William and Coles (2003) stating that length of service does not affect significantly teachers' perception in doing classroom action research.

Table 15

Analysis of Variance of the Teachers' Level of Perception in Conducting Classroom Action Research when Grouped According to Length of Service

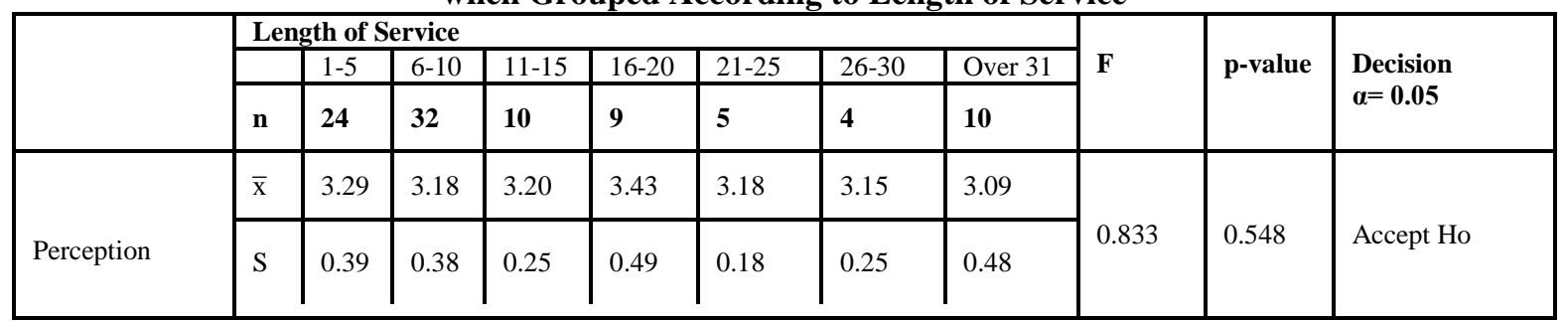

Indicated in Table 16 is the result of the analysis of variance of the teachers' level of capability to undertake classroom action research when grouped according to length of service. As specified, it has a p-value of 0.108 which is greater than 0.05 degree of confidence. Thus, the hypothesis was accepted. This shows that there is no significant difference in the teachers' level of capability in undertaking classroom action research when grouped according to length of service. This implies that the length of service of teachers does not affect their capability to undertake classroom action research. This is also in consonance with the finding of Kunandar (2008) in his study on teachers' capability to undertake classroom action research, which says that the knowledge and trainings to undertake classroom action research affected their capability in doing classroom action research. This is also in consonance with William and Coles (2003) who say that length of service does not significantly affect teachers' capability to undertake classroom action research.

Table 16

Analysis of Variance of the Teachers' Level of Capability to Undertake Classroom Action Research when Grouped According to Length of Service

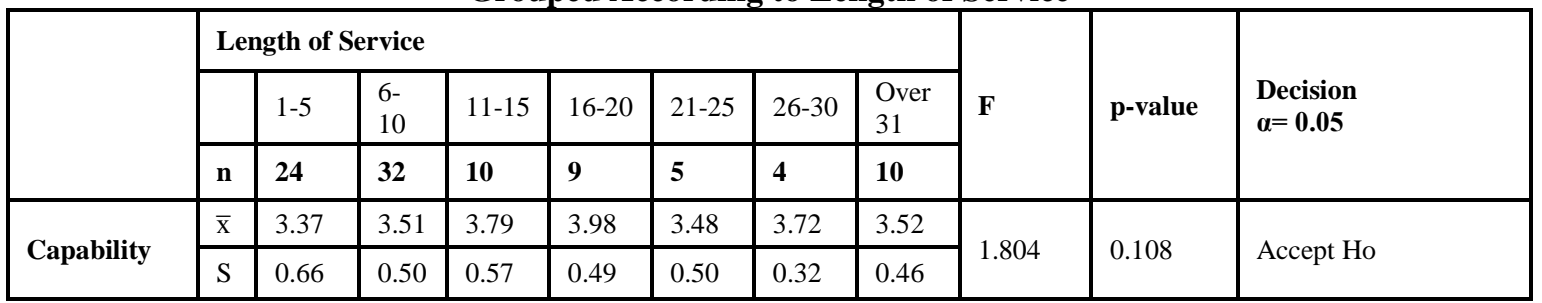


Table 17 shows the result of the analysis of variance of the teachers' level of perception in conducting classroom action research when grouped according to age. As shown, it has a p-value of 0.514 which is greater than 0.05 degree of confidence. Therefore, the hypothesis was accepted. This shows that there is no significant difference in the teachers' level of perception in conducting classroom action research when grouped according to age. This implies that the age of teachers does not affect their perception in doing classroom action research. It is in consonance with Eggen and Kauchak (2001), in their study on cognitive dimension of perception; say that background knowledge in the form of schemes affects perception and subsequent learning.

Table 17

Analysis of Variance of the Teachers' Level of Perception in Conducting Classroom Action Research when Grouped According to Age

\begin{tabular}{|c|c|c|c|c|c|c|c|c|c|c|c|}
\hline & \multicolumn{8}{|c|}{ Age } & \multirow{3}{*}{$\mathbf{F}$} & \multirow{3}{*}{$\begin{array}{l}p- \\
\text { value }\end{array}$} & \multirow{3}{*}{$\begin{array}{l}\text { Decision } \\
\alpha=0.05\end{array}$} \\
\hline & & $\begin{array}{l}20- \\
25 \\
\end{array}$ & $26-30$ & $\begin{array}{l}31- \\
35 \\
\end{array}$ & $36-40$ & $\begin{array}{l}41- \\
45 \\
\end{array}$ & $46-50$ & $\begin{array}{l}\text { Over } \\
51\end{array}$ & & & \\
\hline & $\mathbf{n}$ & 3 & 10 & 22 & 13 & 13 & 14 & 19 & & & \\
\hline & $\overline{\mathrm{x}}$ & $\begin{array}{l}3.1 \\
6 \\
\end{array}$ & 3.25 & $\begin{array}{l}3.2 \\
5\end{array}$ & 3.37 & $\begin{array}{l}3.2 \\
0\end{array}$ & 3.27 & 3.07 & & & \\
\hline Perception & $\mathrm{S}$ & $\begin{array}{l}0.2 \\
6\end{array}$ & 0.22 & $\begin{array}{l}0.4 \\
0\end{array}$ & 0.44 & $\begin{array}{l}0.3 \\
4\end{array}$ & 0.48 & 0.35 & 0.878 & 0.514 & Accept Ho \\
\hline
\end{tabular}

Indicated in Table 18 is the result of the analysis of variance of the teachers' level of capability to undertake classroom action research when grouped according to age. As specified, it has a p-value of 0.040 which is lesser than 0.05 degree of confidence. Thus, the hypothesis was rejected. This shows that there is a significant difference in the teachers' level of capability in undertaking classroom action research when grouped according to age. In favor of those who belong to age 46-50. This is manifested by its mean of 3.96 which is higher than those in the other groups. This implies that teachers who belong to age 46-50 have higher level of capability in undertaking classroom action research compared to those in age of 20-25, 26-30, 31-35, 36-40, 41-45, and over 51. This is also in consonance with the findings of William and Coles (2003), in their study on attitude of teachers towards research tended to vary significantly in relation to research experience, subjects taught, and age.

Table 18

Analysis of Variance of the Teachers' Level of Capability to Undertake Classroom Action Research when Grouped According to Age

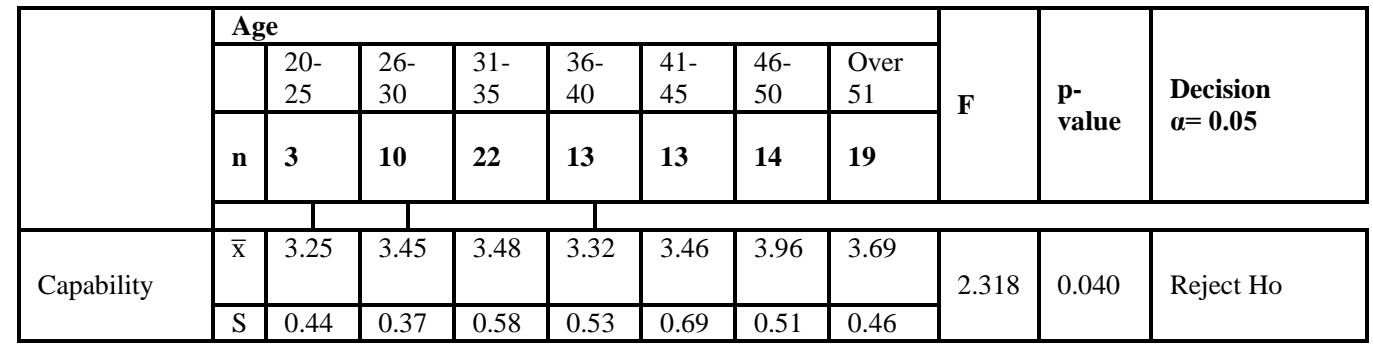

\section{The Significant Relationship between Teachers' Perception and Capability to Undertake Classroom} Action Research

Shown in table 19 is the result of the relationship between teachers' perception and capability to undertake action research. Data show that the p-value of the indicator is 0.008 with the $r$ value is 0.273 . Since the p-value of 0.008 is lesser than the p-value of 0.05 level of significance. Therefore, the hypothesis which stated that there is no significance relationship between teacher's perception and capability in doing classroom action research is rejected. This means that there is significant relationship between teachers' perception and capability in doing classroom action research. This further implies that respondents' perception goes hand in hand with their capability in doing classroom action research. Thus any increase on the level of perception in doing classroom action research will have a corresponding increase on the level of capability to conduct classroom action research. This is also in consonance with the findings of Budi Prasetyo A.P (2010) in his study on learning paradigm of biology teaching, educational background, school culture, perception, attitude, intrinsic motivation, meta cognitive awareness, which says that teachers' educational background, school culture, perception, attitude, intrinsic motivation and meta cognitive awareness all together had significantly an impact on the implementation of classroom action research ( F 4.389, p 0.000) Simultaneous contribution of those 
variables toward classroom action research was $12.8 \%\left(\mathrm{R}^{2}\right.$ 0.128). Teachers' educational background and perception significantly influenced the capability to undertake classroom action research.

Table 19

Relationship between Teachers' Perception and Capability to Undertake Action Research

\begin{tabular}{|l|c|c|c|c|}
\hline & $\begin{array}{c}\text { Capability to } \\
\text { Undertake Action } \\
\text { Research (Y) }\end{array}$ & Interpretation & p-value & $\begin{array}{c}\text { Decision } \\
\alpha=0.05\end{array}$ \\
\hline $\begin{array}{l}\text { Teacher's Perception in } \\
\text { Conducting Classroom Action } \\
\text { Research (X) }\end{array}$ & $\begin{array}{r}\mathrm{r}=0.273 \\
\mathrm{r}^{2}=0.0745\end{array}$ & $\begin{array}{c}\text { Significant Low } \\
\text { Correlation }\end{array}$ & 0.008 & Reject $\mathrm{H}_{\mathrm{o}}$ \\
\hline
\end{tabular}

Table 20 shows the result of the teachers' perception significantly influences their capability undertake classroom action research. Data presented the p-value of 0.008 with the r-value of 0.273 . Since the p-value of 0.008 which is lesser than 0.05 level of significant, then the hypothesis which stated that the teachers' perception does not influence teachers' capability to undertake classroom action research is rejected. This means that the teachers' perception influences their capability to undertake classroom action research. It is interpreted that the teachers' perception influenced their capability to undertake classroom action research. The teachers' perception influences their capability is $7.45 \%$ with the implication that about $92.55 \%$ of that factors influence the respondents' capability to undertake classroom action research are not covered in this study. This is also in consonance with the findings of Budi Prasetyo A.P (2010) in his study on learning paradigm of biology teaching, educational background, school culture, perception, attitude, intrinsic motivation, meta cognitive awareness, which says that teachers' educational background, school culture, perception, attitude, intrinsic motivation and meta cognitive awareness all together had significantly an impact on the implementation of classroom action research (F 4.389, p 0.000) Simultaneous contribution of those variables toward classroom action research was $12.8 \%\left(\mathrm{R}^{2}\right.$ 0.128). This is also in consonance with William and Coles (2003) who say that attitude of teachers towards research tended to vary significantly influence their capability to undertake classroom action research. This is also in consonance with Kunandar (2008) who says that teachers' perception in doing classroom action research influence significantly their capability to undertake classroom action research and so is Maja Miskovic, Efrat Sara Efron and Ruth Ravid (2012). This is also in consonance with Sandra, Andriani, Antoro, Prayekti and Warsito (2011) who say that there is about $12.75 \%$ of teachers' perception influences their capability to undertake classroom action research and so is Little \& King (2007) who says that teachers' perception had significantly an impact on their capability to undertake classroom action research.

Table 20

Teachers' Perception Significantly Influences Their Capability to Undertake Classroom Action Research

\begin{tabular}{|c|c|c|c|c|}
\hline Predictors & $\begin{array}{l}\text { Unstandardized } \\
\text { Coefficients } \beta\end{array}$ & $\begin{array}{l}\text { Standardized } \\
\text { Coefficients } \beta\end{array}$ & $\mathbf{T}$ & p-value \\
\hline (Constant) & 2.274 & & 4.785 & 0.000 \\
\hline $\begin{array}{l}\text { Teacher's } \\
\text { Perception }\end{array}$ & 0.398 & 0.273 & 2.720 & 0.008 \\
\hline $\mathrm{R}$ & \multicolumn{4}{|c|}{0.273} \\
\hline $\mathrm{r}^{2}$ & \multicolumn{4}{|c|}{0.0745} \\
\hline $\mathrm{F}$ & \multicolumn{4}{|c|}{7.400} \\
\hline$p$-value & \multicolumn{4}{|c|}{0.008} \\
\hline
\end{tabular}

Designing Capability Building Program Based on the Findings

The findings of this study show that there is a significant relationship between the teachers' perception and their capability to undertake classroom action research or about $7.45 \%$ of the teachers' perception influences their capability to undertake classroom action research. Since there is a significant relationship between teachers' perception in doing classroom action research and capability to undertake classroom action research, hence, a capability building program should be proposed. Based on the findings, the capability building program that follows is designed to address the needs of the teachers with regards to conducting research.

\section{A Proposed Capability Building Program Rationale}


Developing the culture of research among teachers in indispensable factor for the improvement and development of an institution, it is therefore inevitable to develop the skills and uplift the enthusiasm of the teachers to conduct and engage in research. It is for this reason that the Indonesian foreign school should address this emerging challenge, thus this intervention that is "Capability Building Program" in the scope of "Research Training" for research is formulated.

\section{Program Objectives}

The proposed intervention program has the following objectives:

(1) To enhance teachers' perception in doing classroom action research of the Indonesian foreign schools to conduct classroom action research in terms of: time, cost, image, technicality and effort.

(2) To strengthened the teachers' capability to undertake classroom action research in terms of knowledge, skills, and reason.

(3) To provide budget for teachers to conduct action research per year for 3 (three) teachers.

(4) To monitor the conducting of classroom action research

\section{Proposed Capability Building Program for Research}

\section{Training}

\begin{tabular}{|c|c|c|c|c|c|c|c|}
\hline $\begin{array}{l}\text { Key Result } \\
\text { Areas }\end{array}$ & Objectives & Strategies & Process & $\begin{array}{l}\text { Success } \\
\text { Indicators }\end{array}$ & $\begin{array}{l}\text { Time } \\
\text { Frame }\end{array}$ & $\begin{array}{l}\text { Persons } \\
\text { Involved }\end{array}$ & $\begin{array}{l}\text { Target } \\
\text { Beneficiaries }\end{array}$ \\
\hline $\begin{array}{l}\text { In terms of } \\
\text { time, cost, } \\
\text { image, } \\
\text { technicality }\end{array}$ & $\begin{array}{l}\text { To enhance } \\
\text { their mind } \\
\text { that they can } \\
\text { do classroom } \\
\text { action } \\
\text { research } \\
\text { while } \\
\text { teaching }\end{array}$ & $\begin{array}{l}\text { Holding a } \\
\text { classroom } \\
\text { action } \\
\text { research } \\
\text { training }\end{array}$ & $\begin{array}{l}\text { Propose } \\
\text { classroom } \\
\text { research } \\
\text { training to the } \\
\text { stakeholders }\end{array}$ & $\begin{array}{l}100 \% \text { of the } \\
\text { teachers have } \\
\text { higher }(4.5) \\
\text { scale in their } \\
\text { perception } \\
\text { and } 95 \% \text { of } \\
\text { teachers } \\
\text { attend the } \\
\text { training }\end{array}$ & $\begin{array}{l}2012- \\
2013\end{array}$ & $\begin{array}{l}\text { Consul } \\
\text { General and } \\
\text { School } \\
\text { principal of } \\
\text { the } \\
\text { Indonesian } \\
\text { foreign } \\
\text { schools }\end{array}$ & Teachers \\
\hline $\begin{array}{l}\text { In terms of } \\
\text { Teachers' } \\
\text { capability to } \\
\text { Undertake } \\
\text { Classroom } \\
\text { Action } \\
\text { Research }\end{array}$ & $\begin{array}{l}\text { To enhance } \\
\text { their } \\
\text { capability to } \\
\text { undertake } \\
\text { classroom } \\
\text { action } \\
\text { research }\end{array}$ & $\begin{array}{l}\text { Holding a } \\
\text { classroom } \\
\text { action } \\
\text { research }\end{array}$ & $\begin{array}{l}\text { Propose } \\
\text { classroom } \\
\text { action research } \\
\text { training to the } \\
\text { stakeholders }\end{array}$ & $\begin{array}{l}100 \% \text { of the } \\
\text { teachers have } \\
\text { higher }(4.5) \\
\text { scale in their } \\
\text { capability } \\
\text { and } 95 \% \text { of } \\
\text { teachers } \\
\text { attend the } \\
\text { training }\end{array}$ & $\begin{array}{l}2012- \\
2013\end{array}$ & $\begin{array}{l}\text { Consul } \\
\text { General and } \\
\text { School } \\
\text { principal of } \\
\text { the } \\
\text { Indonesian } \\
\text { foreign } \\
\text { schools }\end{array}$ & Teachers \\
\hline $\begin{array}{l}\text { Allocating } \\
\text { Research } \\
\text { grants for } 3 \\
\text { teachers per } \\
\text { year }\end{array}$ & $\begin{array}{l}25 \% \text { of the } \\
\text { teachers can } \\
\text { do classroom } \\
\text { action } \\
\text { research }\end{array}$ & $\begin{array}{l}\text { Provide } \\
\text { grants to } \\
\text { teachers } \\
\text { who wish to } \\
\text { conduct } \\
\text { research. }\end{array}$ & $\begin{array}{l}\text { Propose policy } \\
\text { or manuals } \\
\text { which cover } \\
\text { the grants and } \\
\text { scholarship for } \\
\text { teachers who } \\
\text { will conduct } \\
\text { research. }\end{array}$ & $\begin{array}{l}3 \text { teachers } \\
\text { acquire } \\
\text { research } \\
\text { grants }\end{array}$ & $\begin{array}{l}2013- \\
2014\end{array}$ & $\begin{array}{l}\text { Consul } \\
\text { General and } \\
\text { School } \\
\text { principal of } \\
\text { the } \\
\text { Indonesian } \\
\text { foreign } \\
\text { schools }\end{array}$ & Teachers \\
\hline
\end{tabular}

\section{Conducting Classroom Action Research}

\begin{tabular}{|l|l|l|l|l|l|l|l|}
\hline $\begin{array}{l}\text { Monitoring of } \\
\text { pesearch }\end{array}$ & $\begin{array}{l}\text { To encourage } \\
\text { the consul } \\
\text { general and } \\
\text { school } \\
\text { principal to } \\
\text { monitor } \\
\text { research } \\
\text { projects of } \\
\text { teachers }\end{array}$ & $\begin{array}{l}\text { Personal } \\
\text { meeting and } \\
\text { conversation } \\
\text { with the consul } \\
\text { general, school } \\
\text { principal and } \\
\text { teacher on the } \\
\text { importance of } \\
\text { monitoring of } \\
\text { research } \\
\text { endeavor }\end{array}$ & $\begin{array}{l}\text { Request } \\
\text { teacher to } \\
\text { present the } \\
\text { schedule } \\
\text { and progress } \\
\text { of his/her } \\
\text { research } \\
\text { project }\end{array}$ & $\begin{array}{l}25 \% \text { of the } \\
\text { teachers } \\
\text { conducted } \\
\text { research }\end{array}$ & $\begin{array}{l}2014- \\
2015\end{array}$ & $\begin{array}{l}\text { Consul } \\
\text { general } \\
\text { School } \\
\text { principal } \\
\text { and Faculty }\end{array}$ & \\
& & & & & \\
& & & \\
& & & & \\
& & & & & \\
& & & & & & \\
\end{tabular}

\section{Recommendations}

After a careful review of the findings, the following recommendations are offered:

(1) In terms of educational background, this study found out that there are still $3.19 \%$ of the respondents are under bachelor or college graduate. The researcher recommends not hiring teachers who are under bachelor since one the Indonesian Regulation No. 20 series of 2003 and Indonesian Government Order No. 19 series of 2005 and No. 17 series of 2010 stated that all teachers from Kindergarten up to High School must be graduate a bachelor degree holder. 
(2) In terms of teachers' perception in doing classroom action research, the researcher recommends to be given some improvements or capability building program to their perception such as research training, research seminar, collaborative research and etc since their perception significantly affects their capability to undertake classroom action research.

(3) In terms of teachers' capability to undertake classroom action research, the researcher recommends to be given some improvements of their capability such as research capability building program since their capability is not very high.

(4) In terms of the significant relationship between teachers' perception and capability to undertake classroom action research, this study found out that there the researcher recommends to all Indonesian Broad School Management (Ambassadors, Consul Generals, and School Principals) to support and to hold Classroom Action Research Training Program, and to allocate some budget to do research for the teachers who served the Indonesian Foreign Schools. To start, the Indonesian School Davao will hold a Classroom Action Research Program for its teachers tentatively on October 19-21, 2012 at Paradise Island Resort (Refer to Appendix C for the program).

(5) It is recommended to Vice-Principals/School Heads to hold the capability building program that could be designed in order to improve the Indonesian foreign schools' classroom instructional management.

(6) It is recommended to teachers to the teachers of different Indonesian foreign schools that they have responsibilities of examining their own practices, increase their capacity to conduct classroom action research which can be used for instructional improvement.

(7) It is recommended through the conduct of classroom action research, students' needs are properly addressed specifically for instructional adjustments and mode of lesson delivery.

(8) Follow up research should be done to evaluate whether the intervention program made was effective or not.

References

[1]. Ames, D. (1993). Motivational characteristics in personality learning. Washington DC: American Psychological Association.

[2]. Apruebo, R. A. (2009) Psychology. Manila, Philippines.

[3]. Aquino, M. (1998). Intelligence on leadership. Manila, Philippines.

[4]. Aritonang, T. K. (2007). Education Problems. Kharisma Putra Utama Offset.

[5]. Bernardo, A. B. (2003). Towards a typology of Philippine Higher Education Institutions. In Towards Rationalizing Philippine Higher Education. Proceedings of the Symposium on the Rationalization of the Philippine Higher Education System. CHED: Philippines.

[6]. Bandura, A. (2006b). Guide for Constructing Self-Efficacy Scales. In F. Pajares \& T. Urdan (Eds). Self Efficacy Beliefs of Adolescents (pp.307-337). Greenwich, Connecticut: Information Age Publishing.

[7]. Budi Prasetyo A.P. (2010). Learning Paradigm of biology teaching, educational background, school culture, perception, attitude, intrinsic motivation, metacognitive awareness. Retrieved on September 19, 2012 from: pasca.um.ac.id/..../5-colletion-abstractBIO-S3-2

[8]. Blasé, J. (1986). A qualitative analysis of sources of teachers stress: Consequences for performance. American Educational Journal, 23(1), 13-40

[9]. Catane, J.A. (2002). Conducting research: A practical application. Quezon City: JMC Press, Inc.

[10]. Chagas, J.O. (2005). Selected factors associated with the development of research culture of higher educational institutions in region xi: Basis for a proposed intensified program. A unpublished dissertation of University of Mindanao, Davao City.

[11]. Clemena Rose Marie Salazar and Almonte-Acosta A. Sherlyn (2012) Developing Research Culture in Philippines Higher Education Institutions: Perspective of University Faculty. De La Sale University-Manila, Philippines. Retrieved on April 21, 2012 from: www oerafrica.org.

[12]. Cuizon R.O. \& Cayogyog A.O. (2011) Capability, Culture and Passion for Research of the University of the Immaculate Conception Graduate School Research Classes. University of the Immaculate Conception, Davao City, Philippines.

[13]. DiGiulio, R. (2000). Positive classroom management. Corwin Press, Inc.

[14]. Eagly, A. H., \& Chaiken, S. (1993). The psychology of attitudes. Fort Worth: Harcourt Brace Jovanovich College Publishers

[15]. Eggen P, Kauchack D. (2001) Educational Psychology: Windows on classrooms. New Jersey Prentice Hall, Inc. Retrieved on September 19, 2012 from http//www.academicjournals.org/ERR

[16]. Frankel, J. R. and Wallen, N.E. (1993). How to design and evaluate research in education. New York: McGraw Hill

[17]. Gall, G. (2000). Social and educational change: Conceptual frameworks. Comparative Education Review, Volume 28, pp 203-220.

[18]. Glatthorn, A. (1995) “Teacher Development." In: Anderson, L (Ed), International encyclopedia of teaching and teachers education (second edition). London: Pergamon Press

[19]. Greenwood, C.,\&Abbot,M. (2001). The research to practice gap in special education. Teacher Education and Special Education, 24(4),276-289.

[20]. Harpaz, I. (1990). The importance of work goals: an international perspective. Journal of International Business Studies, $21.75-93$.

[21]. Henson, K.T. (1996). Teachers as researchers. In Handbook of research on teacher education, 2nd ed., eds. J. Sikula, T. Buttery, \& E. Guyton, 53-64. New York: Simon \& Schuster.

[22]. Indonesian School of Davao, (2012). Information System Management. Retrieved on April 26, 2012 from www.siln davao.com.

[23]. Indonesian Deped Order No. 16 series of 2007. Teachers Competence Standard, Department of Education. 
[24]. Indonesian DepEd Order No. 191/81/01 and DFA No. 051/U/1981 series of 1981

[25]. Indonesian Deped Order No. 025/0/1995. Guided Professional Credits. Department of Education, Jakarta.

[26]. Igwe, L.E.B. (2005). Instructional to educational administration. Port Harcourt. Global Link Communication Internationa

[27]. Kemmis, S., McTaggart, R. (1988) The Action Research Planner ( $3^{\text {rd }}$ ed.) Geelong, Australia: Deakin University Press.

[28]. Kemmis, S. \& McTaggart, R. (2000). Participatory action research: Communicative action and the public sphere. In Handbook of qualitative research. $2^{\text {nd }}$ ed.,Ed. Norman K. Denzen and Yvona S. Lincoln (pp.559-604). Thousand Oaks, CA: SAGE Publisher.

[29]. Kooij, Jansen, De Lange \& Dikkers (n.d) Retrieved September 20, 2012 from http://szethe.files.wordpress.com/2010/12/agerelated-factors-in-the-motivation-to-work.pdf

[30]. Kovach, K.A. (1987). What motivates employees? Workers and supervisors give different answers. Business Horizon, 30. 58-65.

[31]. Kunandar, (2008). Steps in Doing Classroom Action Research. Kharisma Putra Utama Offset.

[32]. Lindner, J.R. (1998). Understanding employee motivation. Published Research, Ohio State University, Ohio, USA. Retrieved from www.joe.org/joe/1998june/rb3.php

[33]. Little and King. (2007). Using on-line modules for professional development in action research: Analysis of beta testing results. Journal of Interactive online learning. V. 6 No.: 2.

[34]. Martires, Conception R.. (2010). Human Behavior in Organizations. Cacho Hermanos, Inc. Mandaluyong City, Philippines.

[35]. Maksum, Andriaty Etty, Kusmayadi Eka, and Sri Sundari Tuti (2010) The Use Agriculture Research in Government and Non Government Agencies by Researchers and Coach. Retrieved on April 21, 2012 from: pustaka.litbang.deptan.go.id/publikasi/pp 191102.pdf.

[36]. Maja Miskovic, Efrat Sara Efron, and Ruth Ravid. (2012). Action Research in Action: From University to School Classroom .Education Research International, vol.2812, Article ID 389736,11 pages.2012.doi:10.1155/2012/389736. Retrieved on October 7, 2012 from: www.hindawi.com/journals/edu/2012/389736.

[37]. Meiland, J. \& Rosenthal, J.T. (1995). Two faculty member's carreer. Academe 80:28-29.

[38]. Mertens, D.M. (1998). Research methods in education and psychology: Integrating diversity with quantitative and qualitative approaches. SAGE Publications.

[39]. Meyer, K.A. (1998). Faculty workloads studies: perspective, needs, and future directions. ASHE-ERIC Higher Education Report 26(1): 1-101.

[40]. Morton and Gerrard. (1955). A study of normative and informational social influences. Retrieved on April 21, 2012. From: http//doi.apa.org.psycinfo/1957-02366-001

[41]. Oja, S.N., and Pine, G.J. (1989. Collaborative action research: Teachers' stages of development and school contexts. Peabody Journal of Education 64 (2): 96-115.

[42]. Paynter, J.L. (2004). The motivational profiles of teachers: Teachers' preferences for

[43]. extrinsic, intrinsic, and moral motivators. Dissertation, The John Hopkins University

[44]. Rhodes, S.R. (1983). Age-related differences in work attitudes and behavior: A review

[45]. and conceptual analysis. Psychological Bulletin, 93 (2), $328-367$.

[46]. Ruddock, J. and Hopkins, D. (1985) Research as a basis for teaching: readings from

[47]. the work of Lawrence Stenhouse. London: Heinemann Educational Books.

[48]. Rust, F.O. (2007). Action research in early childhood contexts. In Early childhood qualitative research, ed. J.A. Hatch, 95-108. New York: Routledge.

[49]. Sandra, S.A.D., Antoro, A.S.D., Prayekti, and Warsito (2011) Excellence in higher education, Volume 2, Number 2. Retrieved March 25, 2012 from http://che.plt.edu.

[50]. Sharobeam, M.H. \& Howard, K. (2002). Teaching demands versus productivity. Journal of College of Science and Technology, 31 (7): 436-441.

[51]. Stringer, E. (2004). Action research in education. Columbus, Ohio: Pearson Merrill Prentice Hall.

[52]. Stenhouse, L. (1975) An introduction to curriculum research and development. London: Heinemann)

[53]. Supraptono Eko. (2012) Teachers' Performance in Doing Classroom Action Research is still Low. Retrieved on September 17,2012 from: pps.unes.ac.id/.../kinerja-guru.html.

[54]. The New Lexicon Webster's Dictionary of English Language (2004). Danbury, CT: Lexicon Publications.

[55]. Websters, N. (2002). Webster's new international dictionary ( $3^{\text {rd }}$. ed.). Massachusetts: Merriam-Webster Inc.

[56]. Williams, D. and Coles, L. (2003). The use of research by teachers: Information literacy, access, and attitudes. Scotland: The Robert Brown University.

[57]. Winkler, A.M. (1996). Explaining what professors do with professors. The Chronicle of Higher Education. 15 July 1996. 38, 0. B1 $-\mathrm{B} 2$.

[58]. Zulueta, F.M. and Perez, J.R. (2010). Methods of research: Thesis writing and applied statistics. Manila: National Bookstore. 